\title{
CHARACTERIZATION OF THE COMMERCIAL FISH PRODUCTION LANDED AT MANAUS, AMAZONASSTATE, BRAZIL
}

\author{
Vandick da Silva BATISTA", Miguel PETRERE JÚNIOR²
}

ABSTRACT: The present work aims to update a series of information about the regional fishing production, by presenting and characterizing the contribution of the different sub-systems of the Amazon basin to the catch landed at the main fishing market of Manaus, Brazil, from 1994 to 1996. Collectors specifically hired for this function registered key information on the fisheries. Thirty nine types or groups of fish were found in the fishing production landed. Jaraqui (Semaprochilodus spp.), curimatã (Prochilodus nigricans), pacu (Myleinae), matrinchã (Brycon cephalus), sardine (Triportheus spp.), aracu (Anostomidae) and tambaqui (Colossoma macropomum) were the most important items during three consecutive years. In 1994 these items summed up $91.6 \%$ of the total production; in 1995 and 1996 these values were, respectively, $85.3 \%$ and $86.4 \%$ of the total production. Tambaqui landed decreased remarkably during the period 1976-1996. There was a strong seasonal component in the production of the main species; jaraqui and matrinchā were mostly landed between April and June, while curimatā, pacu, and sardine were mostly landed during the dry season. Other important items showed a strong inter-annual variation in their production. The fishing production landed came mostly from the sub-system of the Purus River (around 30\% of the total production). The subsystem of the Medium-Solimões contributed with an average of $15 \%$ and the sub-systems of the Madeira, Lower-Solimões, Upper-Amazon and Juruá, together contributed with $11.5 \%$ of the total production landed. Finally, the remaining sub-systems contributed with only $7.6 \%$ of the production.

KEYWORDS: fish, fisheries, Amazon, production

\section{CARACTERIZAÇÃO DA PRODUÇÃO PESQUEIRA DESEMBARCADA PELA PESCA PROFISSIONAL EM MANAUS, AMAZONAS, BRASIL}

RESUMO : O presente trabalho visa atualizar uma série de informação sobre a produção pesqueira regional, apresentando e caracterizando a contribuição dos diferentes sub-sistemas da Amazônia Central para a captura desembarcada no principal mercado pesqueiro de Manaus entre 1994 e 1996. Coletores foram contratados para registrar informações chave sobre as pescarias efetuadas. Foram registrados 39 tipos ou grupos de peixe na produçāo pesqueira desembarcada. Jaraqui (Semaprochilodus spp.), curimatã (Prochilodus nigricans), pacu (Myleinae), matrinchã

\footnotetext{
${ }^{1}$ Universidade Federal do Amazcnas, Faculdade de Clências Agrárias, LFPECA/Laboratório de Avaliação e Marejo da Pesca, Campus Universitário, Manaus, $7 \mathrm{M}, 69077-000$, email: ibatistaqufam.edu.br

${ }^{2}$ UETP, Camps Rio Claro, Depto. Erologia, Qx. Postal 199, Rio Claro, Sáo Falo, 13506-900, email: mpetrerearc.uneqp br
} 
(Brycon cephalus), sardinha (Triportheus spp.), aracu (Anostomidae) e tambaqui (Colossoma macropomum) foram os itens mais importantes durante os três anos sucessivos. Em 1994 estes itens totalizaram 91,6\% da produção total; em 1995 e 1996 estes valores representaram, respectivamente, $85,3 \%$ e $86,4 \%$ da produção total. A quantidade de tambaqui desembarcada diminuiu notavelmente ao longo do 1976-1996. Há um componente sazonal na produção das principais espécies: jaraqui e matrinchã foram desembarcados principalmente entre abril e junho, enquanto que curimatā, pacu, e sardinha foram desembarcados principalmente durante a estação seca. Outros itens importantes mostraram uma forte variação interanual na produção. A produção pesqueira desembarcada foi originada principalmente do sub-sistema do Rio Purus (ao redor 30\% da produção total). O sub-sistema do Médio-Solimōes contribuiu com uma média de 15\% e os sub-sistemas do Madeira, Baixo-Solimões, Alto-Amazonas e Juruá, juntos contribuíram com $11,5 \%$ da produção total desembarcada. Os demais sub-sistemas contribuíram apenas com $7,6 \%$ da produção total.

PALAVRAS-CHAVE: peixes, pesca, Amazônia, produçāo pesqueira.

\section{INTRODUCTION}

The knowledge about fishing in Central Amazonia showed a great expansion at the end of the 1970's, when a generation of researchers developed a series of studies that rendered pivotal information for the understanding of the fishing activity (Petrere, 1978a/b, 1983a and 1985; Goulding, 1979 and 1981; Smith, 1979 among others), as well as about the dynamics of the exploited populations (Petrere, 1983b; Ribeiro, 1983; Bayley, 1983; Junk, 1984, among others). However, during the 1980's such studies became restricted to the contribution of Merona and co-workers (e.g. Merona \& Bittencourt, 1988; Merona \& Gascuel, 1993), a situation worsened by the interruption of the fisheries statistics in the main fish landing market by the INPA in 1986 and by the SUDEPE in 1988. Only after January 1994, their work was resumed in Manaus, this time by the Federal University of Amazonas, Brazil.
In the present work, a part of this information is analyzed, seeking to determine the qualitative and quantitative evolution of the fishing production landed in Manaus as well as the temporary variation of the contribution of the different sub-systems of the Amazon basin to the provisioning of fishing production in this area. Such analysis constitutes a way of contributing to the identification of important areas for the development of the fishing activity; at the same time, we hope it will supply useful information to the ecological-economic zoning in the area.

\section{MATERIAL AND METHODS}

Hired collectors accompanied the fishing landed at the Feira do Panair, Manaus. They registered the following information: dates of arrival; name of the fishing boat; local and type of the fishing ground; type and characteristics 
of the gear used; number of fishermen; days spent fishing; amount of catch per fish item (common name of may group species); price per type of fish; amount of fuels and lubrificants used; and amount of ice acquired.

These collectors were also trained in order to obtain data on fork length of at least 30 individuals per fish item per night, for 10 randomly-selected days in a month, so that up to 300 measurements were taken during this period. Fish production recorded in numbers were transformed to weight using mean length recorded and length-weight relationships from various papers and unpublished reports or calculated from our own data. The calculation of the catch effectively landed followed the procedures of Merona \& Bittencourt (1988), considering that the catch effectively landed is, in fact, $10 \%$ higher than the one declared.

The daily level of the rivers in preselected stations per sub-system (Óbidos, Borba, Manicoré, Parintins, Manaus, Beruri, Canutama, Manacapuru, Maraã, Ipixuna, Tabatinga) were supplied by ANEEL (Brazilian Electric Energy Agency) for the whole period. However, as the lack of data for several days could seriously bias the monthly average, we opted for taking averages values starting from the levels registered on the $14^{\text {th }}, 15^{\text {th }}$ and $16^{\text {th }}$ days of each month, considering lost the data for those months without data for these days.

The calculation of the weight-length regressions and of the conversion unit for weight, and variance analyses were carried out by statistical software, with the theoretical background of Sokal \& Rohlf (1981).

\section{RESULTS}

\section{Landed items}

Ninety-nine different common names were registered for a variety of thirty-nine types or groups of fish found in the fishing production landed (Table 1). We also presented, besides the common names, the closest scientific identification.

\section{Fish production}

Table 2 presents the landed items and the production per item for the years of 1994 , 1995 and 1996, respectively. It can be noted that jaraquis, curimatā, pacu, matrinchā, sardine, aracu and tambaqui are the most important species during three consecutive years. In 1994 these species summed up 91.6\% of the total production; in 1995 and 1996 these values were, respectively, $85.3 \%$ and $86.4 \%$ of the total production

The data for the period 1994-1996 were plotted as a function of the production of jaraqui, curimatã, pacu, tambaqui, matrinchã and tucunaré (Fig. 1), along with available information in the literature for the period 1976-1986 (Merona \& Bittencourt, 1988). For jaraqui, we observed an increase in the production up to $1984-1985$, with a reduction in 1986 and stabilization, at the same levels observed for 1980-1983, during the period 1994-1996. Curimatã was the only species that presented a continuous increase in its production along the studied period; pacu and matrinchã showed a notable variation, ranging from 200 to $400 \%$ in their productions among consecutive years. The tambaqui production landed showed a reduction along the historical series, albeit with occasional periods of 
Table 1 - List of the fish types found at the Manaus Fish Market, with scientific identification as detailed as possible.

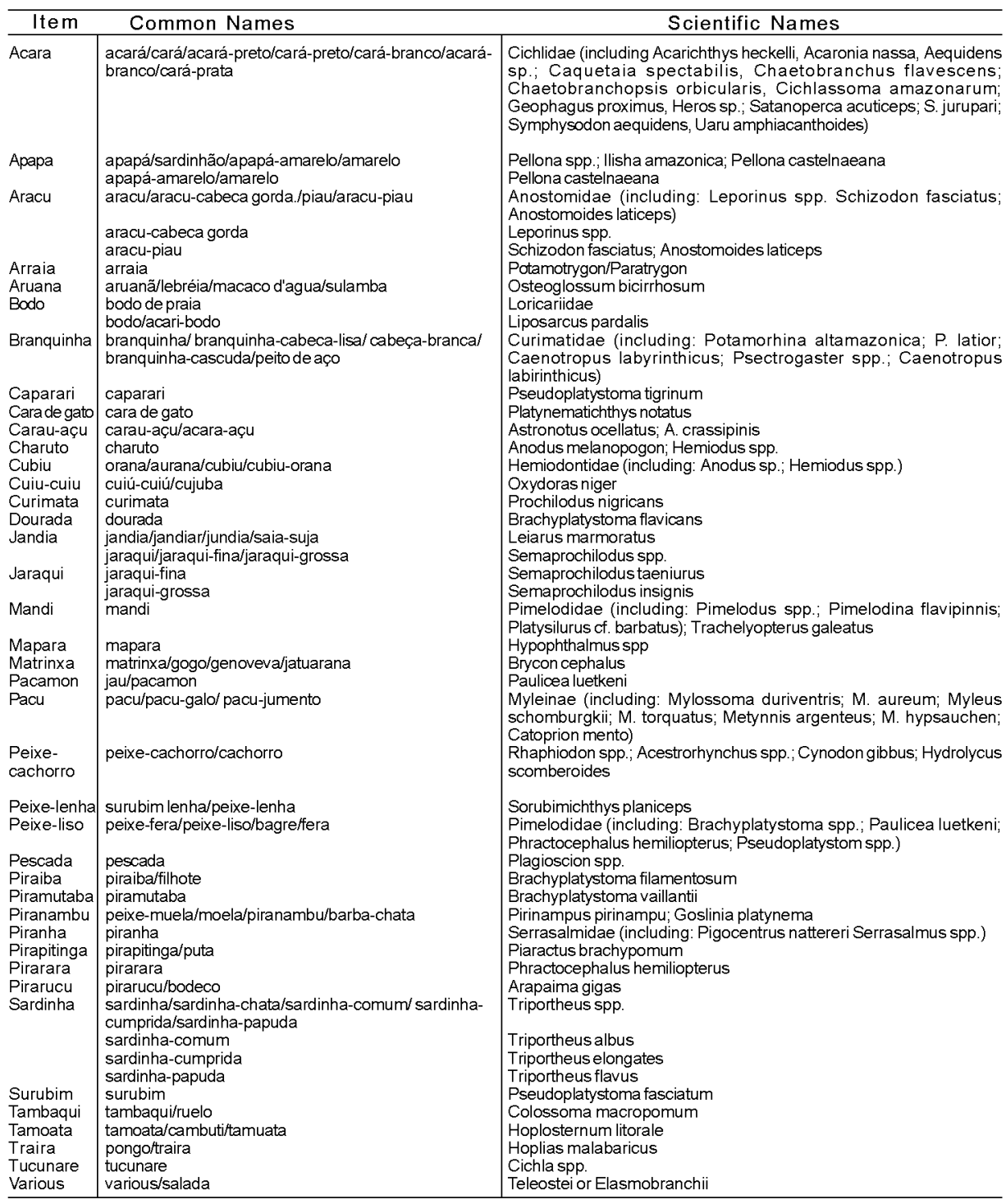

production recoveries; the resulting patterns showed a consistent decrease in the period, with an actual annual production of around 1000 tons. Tucunaré showed a stable production until 1980-1981, and a reduction from the end of this period until 1986. This pattern remained stable until 1996 , with an over-production of 800 tons in 1995-1996, a level previously observed only in 1979 .

The seasonal variation of the production showed a peak between August and October of 1994 and 1995, a minimum between December and March of the same years, and intermediate values in April, June, July and November of all 
Table 2 - Monthly fish production corrected in tons, per item landed at the Manaus Fish Market, Manaus from 1994 to 1996.

\begin{tabular}{llll}
\hline Item & \multicolumn{1}{c}{1994} & \multicolumn{1}{c}{1995} & \multicolumn{1}{c}{1996} \\
\hline Apapá & 41,90 & 40,18 & 11,38 \\
Aracu & 2596,62 & 941,87 & 956,84 \\
Arraia & 0 & 1,48 & 0 \\
Aruanã & 370,24 & 391,58 & 401,62 \\
Bodó & 26,20 & 32,26 & 5,40 \\
Branquinha & 332,02 & 476,27 & 290,84 \\
Caparari & 8,80 & 13,03 & 8,50 \\
Cara & 156,67 & 162,10 & 18,30 \\
Cara de Gato & 0 & 086,76 & 10,17 \\
Carau-Açu & 59,36 & 89,17 & 12,65 \\
Charuto & 4,88 & 0 & 22,06 \\
Cubiú & 178,98 & 106,02 & 171,98 \\
Cuiú-Cuiú & 6,43 & 189,65 & 43,90 \\
Curimatã & 4689,52 & 3421,03 & 5126,76 \\
Dourada & 12,44 & 28,64 & 4,48 \\
Jandiá & 1,64 & 0,41 & 0 \\
Jaraqui & 7292,14 & 4722,31 & 6390,14 \\
Mandi & 0 & 0 & 24,22 \\
Mapará & 103,23 & 38,41 & 83,99 \\
Matrinchã & 1885,94 & 864,64 & 3270,23 \\
Pacamão & 2,02 & 0,20 & 0,18 \\
Pacu & 4755,28 & 2130,82 & 2149,44 \\
Peixe-Liso & 5,32 & 48,38 & 1,01 \\
Pescada & 187,76 & 277,95 & 105,72 \\
Piraíba & 8,79 & 2,16 & 0,79 \\
Piramutaba & 3,86 & 0,88 & 0,24 \\
Piranambu & 0 & 8,38 & 0 \\
Piranha & 54,48 & 18,25 & 0,08 \\
Pirapitinga & 269,65 & 242,39 & 1066,35 \\
Pirarara & 0,68 & 0,44 & 0,86 \\
Pirarucu & 67,13 & 15,80 & 0 \\
Sardinha & 1094,00 & 1716,77 & 1666,94 \\
Surubim & 30,21 & 58,61 & 92,22 \\
Surubim-Lenha & 0 & 031,10 & 1,19 \\
Tambaqui & 656,10 & 5231,77 & 821,25 \\
Tamoatá & 0 & 0,39 & 0 \\
Traíra & 9,78 & 17,82 & 13,96 \\
Tucunaré & 160,72 & 871,55 & 0 \\
Various & 11,99 & 0 & 23589 \\
\hline TOTAL & 25084 & 22322 & \\
\hline & & & \\
\hline
\end{tabular}

years (Fig. 2). The month of May stands away from this pattern, as the production during this month was high during the three years of this study, without configuring a tendency with the following months. The production was higher during the flooding period of 1996 in comparison with the previous years, although the production during the dry period of this year was the lowest reported during the three years of this study. These differences among years became evident in Figure 3, where we observe that the scatterplot of production against level of the river shows a great dispersion, indicating the absence of correlation between these variables $(\mathrm{P}>0,05)$. In 1995, however, there were larger catches when the level of the river was low and small catches when this level was high. In 1996 there was a lower degree of dispersion in the scatterplot than in 1994, larger catches being recorded at high levels of the river. 


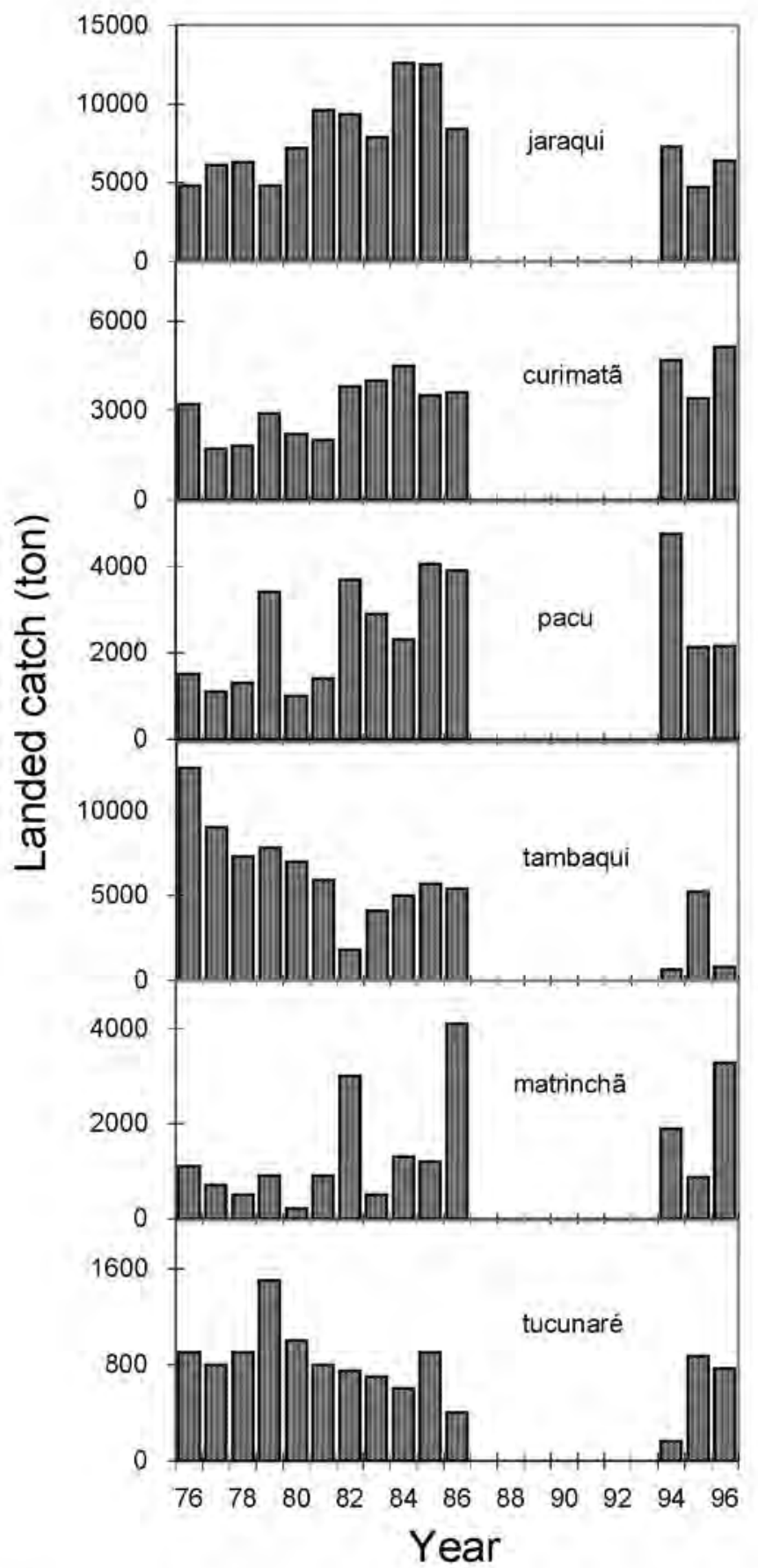

Figure 1. Inter-annual variation in the amount of fish (tons) landed between 1976-1988 (Merona \& Bittencourt, 1988) and 1994-1996. 


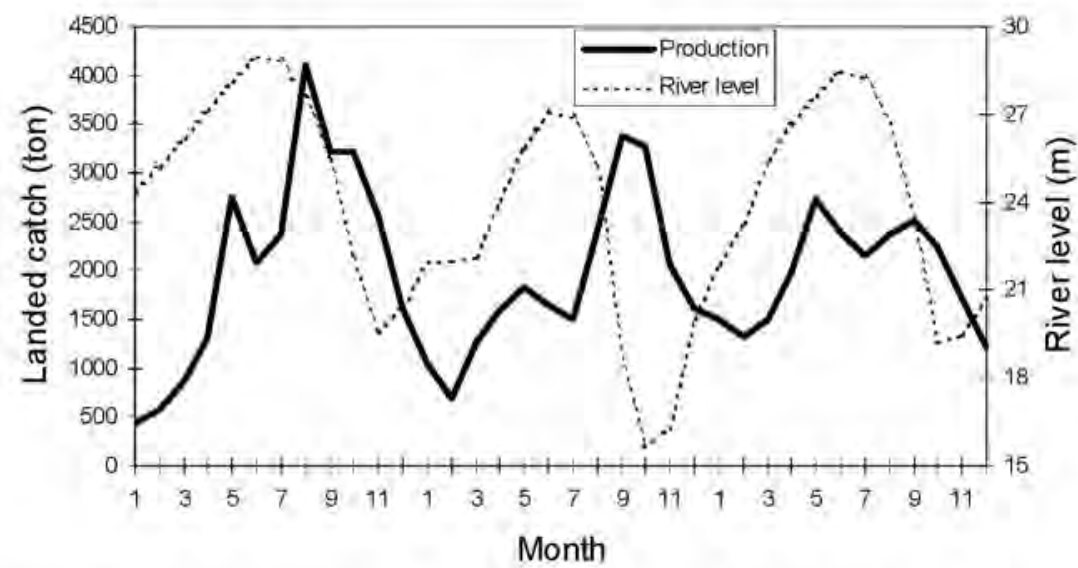

Figure 2. Monthly variation in the production landed at the Manaus Fishing Harbor between January 1994 and December 1996. Dashed line refers to the mean river level at Manaus.

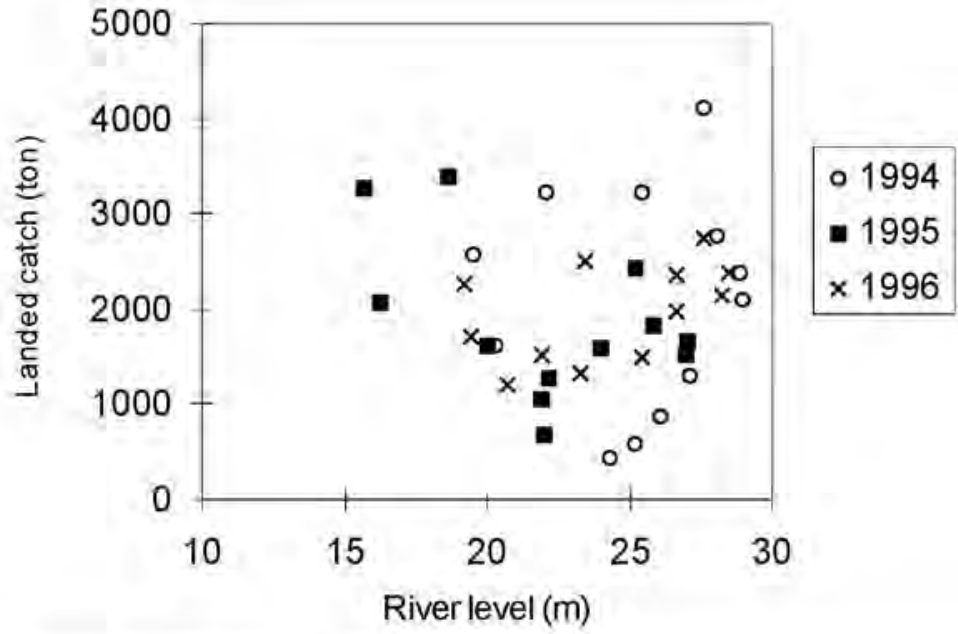

Figure 3 . Dispersion diagram of the total capture landed per month versus the mean river level at Manaus, for the years 1994, 1995 and 1996. 
Evaluating the seasonality of the production for the most important species (Fig, 4) we observe, as a general pattern for the three years, that jaraqui and matrinchâ were landed mostly between April and June. during the middle of the dry season, had an exceptionally catch rate in 1995, starting in the end of the flood season and extending throughout the low water season. Aruana showed a high catch rate at the end of the flood
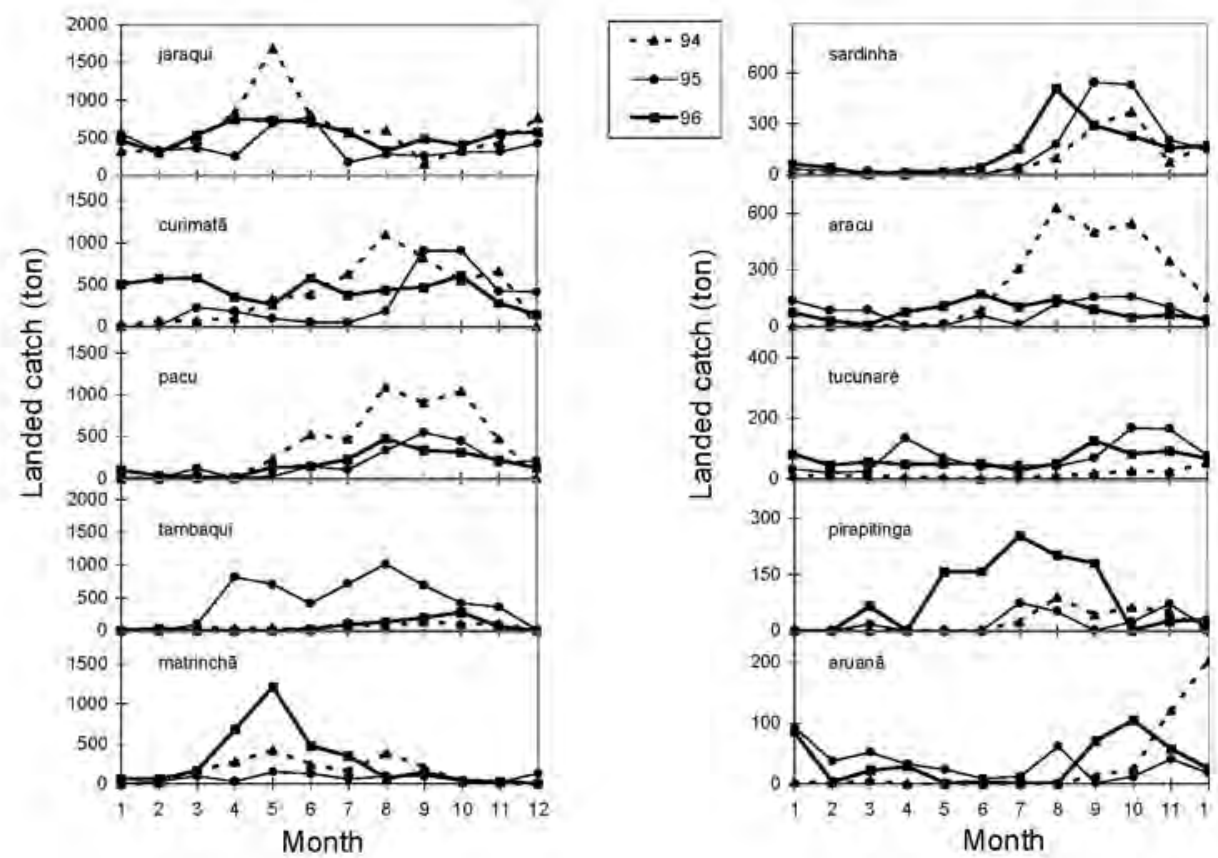

Figure 4. Monthly variation of the production landed at the Manaus Fishing Harbor between January 1994 and December 1996, for the most important commercialized items.

Curimată, pacu, sardine and, to a lesser extent, tucunare, were mostly landed in the low water season, between August and November. Oiher species showed peaks in their catch, which varied in magnitude. Pirapitinga usually has a large revenue in the drain water season (August-September), but presented an exceptional production in 1996 from May to September. Tambaqui, which is mostly caught season in 1994 but this pattern changed in 1995 and 1996. when most of the production were observed at the end of the dry season and at the beginning of the flood season. respectively. Finally, aracu, whose production was exceptional in the drought of 1994 , showed a low production in the next drought and a high production during the flood season of 1996. 


\section{Origin of the fish production}

The fishing production landed came mostly from the sub-system of the Purus River during all the studied period (around $29 \%$ of the total production - Table 3) which was also the most visited (29\% of fishing trips). The sub-system of the MediumSolimões River contributed with an average of $14.7 \%$ of the total production $(13.4 \%$ of fishing trips). The sub-systems of the that there was reduction in the contribution of the Solimōes, Japurá and Jutaí Rivers, and an increase of the contribution of the Purus, Juruá, Madeira and Negro Rivers. The Amazonas River did not present a noteworthy tendency in its contribution.

\section{DISCUSSION}

The amount of fish species in the Amazon surpasses the magnitude of 1500

Table 3 . Relative participation of the sub-systems in the fishing trips done and in fishery production landed between 1994 and 1996.

\begin{tabular}{lllllllll}
\hline & \multicolumn{3}{c}{ \% of fishing trips } & \multicolumn{5}{c}{ \% of fishing production } \\
\cline { 2 - 9 } Main sub-system & 1994 & 1995 & 1996 & \% Total & 1994 & 1995 & 1996 & \% Total \\
\hline Purus & 29.0 & 27.9 & 29.7 & 28.8 & 28.8 & 29.2 & 29.1 & 29 \\
Medium Solimões & 13.4 & 12.3 & 14.8 & 13.4 & 17.8 & 12.7 & 13.5 & 14.7 \\
Madeira & 13.5 & 13.5 & 13.1 & 13.4 & 14.8 & 10.2 & 12 & 12.3 \\
Lower Solimões & 20.3 & 12.8 & 11.4 & 16.2 & 17 & 9.8 & 9 & 11.9 \\
Upper Amazonas & 8.3 & 15.9 & 14.9 & 11.9 & 8.4 & 15.9 & 8.7 & 11 \\
Juruáy & 3.2 & 7.4 & 6.2 & 5.0 & 3.8 & 15.8 & 9.7 & 9.8 \\
Various & 4.9 & 3.6 & 4.0 & 4.3 & 4.7 & 3.4 & 13.3 & 7.1 \\
Negro & 7.5 & 6.6 & 5.9 & 6.9 & 4.9 & 3.2 & 4.7 & 4.3 \\
\hline
\end{tabular}

Madeira, Lower-Solimōes, Upper-Amazonas and Juruá, together contributed with $45 \%$ of the total production landed, with each subsystem contributing from 3.7 to $17.4 \%$, depending on the year and area. LowerSolimöes was the second most visited subsystem (16.2\% of fishing trips) but just yielded $11.9 \%$ of the total production, whereas Juruá River ranked in the fourth place in terms of production (9.8\%), although it was only the seventh in terms of number of trips (5\%). Finally, the remaining sub-systems contributed with only $11.4 \%$ of the production and accounted for $11.2 \%$ of the fishing trips.

The historical variation in the landed catch of the sub-systems is presented with a comparison among the periods of 1976-78 (Petrere, 1982) and 1994-96 (Fig. 5). It is clear species (Kullander, 1994 apud Junk et al., 1997). This great richness of the Amazon fish fauna is a general paradigm (e.g. Roberts, 1972; Junk et al., 1997) that allows reproducing the traditional concept of abundant and permissible richness of intense economic exploration. As far as fisheries are concerned, there is a frequent mention to the underutilization of this richness, which is worsened by the usual habit of listing several species under a same common name. This, in turn, leads to "species" lists with only 30 to 40 items, suggesting a low use of the variety of existent species.

Comparing the present list with the one assembled by Petrere (1978a), it can be noted that it shows a higher variety of fish types; that, can be ascribed to the registration of sub- 


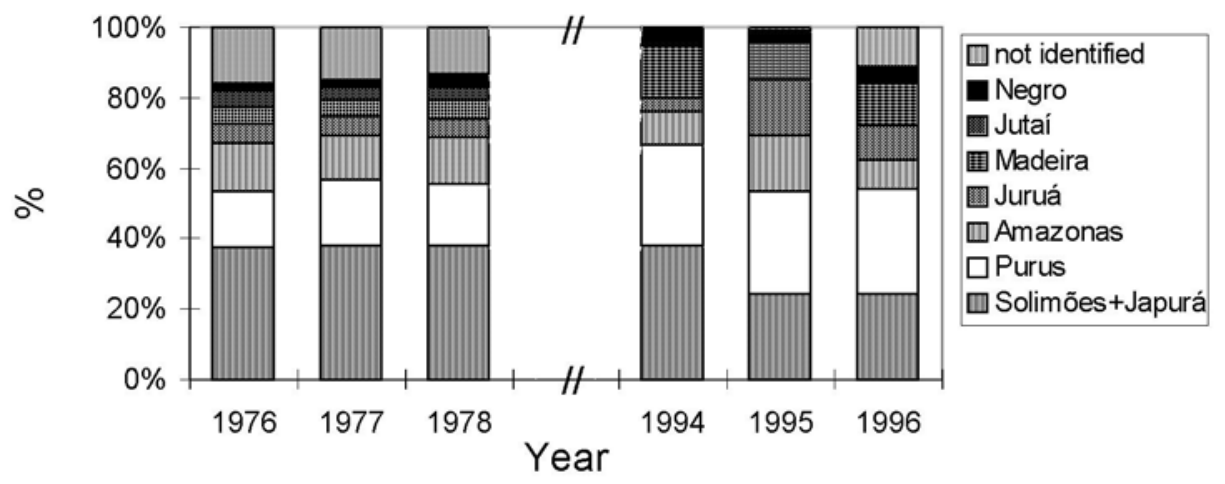

Figure 5 . Comparison of the relative importance of the fishing regions to the fish landed at the Manaus Fishing Harbor between 1994-1996 with those between 1976-1978, accordingly to Petrere (1982).

types within the general types listed in 1978 and whose methodological reasons are difficult to interpret, so, it is assumed that the group of explored species remained the same.

Considering that the diversity of the Amazon fishes is the characteristic most frequently mentioned when the development of the fishery potential of the area is discussed, the traditional concentration of the fishing on few species is often cited as an indication of a great potential to be explored in the area (Bayley, 1981; Pereira-Filho et al., 1991). However, this is an exaggerated concept, because there are at least 20 main species listed during the landings in Manaus of the commercial fishery: jaraquis (with two species and a hybrid), pacu (mainly Mylossoma duriventre, but also with at least other five species), sardine (with at least three species of genus Triportheus), and aracus, with at least seven species (Goulding, 1979; Santos et al., 1984; Ferreira et al., 1996). Curimatã, matrinchã and tambaqui, so far, consisted of just one species each. This situation, associated with the number of commercialized items, suggests that there is at least 100 species being exploited for commercial purposes. Also, the species more frequently explored seem to be those with the highest abundance. Habitats with high diversity are associated with a low abundance per species, or high equitability, which does favor the multispecies commercial exploration.

In addition to this, we had over the last 20 years the expansion of the siluriforms fishing in the Amazon area, which is linked to the installation of freezing houses qualified for exportation of the fishery production of the area (Barthem \& Goulding, 1997); in Central Amazonia this process is still more recent, being developed in the 1990s. Albeit being in expansion, the existence of alimentary taboos in Central Amazonia against the consumption of species of this order, supposedly because its meat have negative properties, is responsible for its small participation in the landings at Manaus. This taboo protected this group from being exploited in the area along the history, a fact that is changing due to commercial aspects and cultural influence. The breaking of a taboo in a society represents, on the anthropological side, a cultural change, 
and on the biological-fishing side, the retreat of the protection to which a group was submitted (Chapman, 1989). Once the interest in the siluriforms appeared, the technology for its capture quickly developed, starting from a change of knowledge with fishermen of low Amazon, which are experienced in the fishing for this group (Barthem, 1990; Barthem \& Goulding, 1997). Consequently, it increased the exploitation efficiency of the species of this order for export purposes. Except for the siluriforms, no other fish group commonly caught is ostensively rejected for consumption by local population, so the existence or not of exploitation is a function of the availability of markets and of the target species in accessible grounds.

There are none indications of changes in the preference of the population for a given fish type, particularly in the case of tambaqui, according to information from fishermen and merchants of outlets and markets of Manaus. The market demand for tambaqui is still high, although the decline in its production is noteworthy and more evident when observed along the sequences of historical production. This species was considered under-exploited by Petrere (1983b) until 1978, but Merona \& Bittencourt (1988) showed evidences of overexploitation when historical data until 1986 were analyzed and Isaac \& Ruffino (1996) recorded growth overfishing for tambaqui of the low Amazonas region. The current situation confirms the over-exploitation pattern; but the causes underlying this pattern need to be elucidated.

The legal norm 08/1996 of the Brazilian Environmental Agency - IBAMA (which updated the legal norm $n^{\circ} 47$ of SUDEPE) forbids the catching of tambaqui smaller than $55 \mathrm{~cm}$ in total length (TL). This legislation was reasonably executed during the 1970 s, mainly because there was enough availability of individuals of this species higher than $55 \mathrm{~cm}$ TL in the fishing grounds exploited by the fleet. More recently, only $41 \%$ and $11 \%$ of tambaqui landed in 1995 and 1996, respectively, obeyed this minimum size; in fact, individuals with a fork length (FL) of only $18 \mathrm{~cm}$ could be found in the market. Given that the size at first maturation is around 60 $\mathrm{cm}$ TL (Villacorta-Corrêa, 1997) and that the species reaches at least $107 \mathrm{~cm}$ TL (Petrere, 1982), then we have strong indications of growth overfishing of this species. Isaac \& Ruffino (1996) estimated the yield-per-recruit curve for tambaqui of the Low-Amazon and also detected growth overfishing in this area. Payne (1987) and Villacorta-Corrêa (1997) obtained a smaller growth rate than those reported by the previous authors. This data indicates that a more critical situation exists for the Mamoré River and for the Central Amazonia.

A stock in the initial phase of exploitation shows higher mean size and lower growth rates than that subjected to a period of intensive exploitation (Hilborn \& Walters, 1992). If tambaqui stocks of the Central Amazon have reacted to fishing exploitation, its current value of $\mathrm{K}$ should be larger than it would have been $20-30$ years ago, when there was no overfishing recorded. However, $\mathrm{K}$ does not increased, implying that the growth overfishing has not been strong enough to generate responses in growth parameters or that the species growth is not related to the intra-specific density or abundance at the occurred levels. On the other hand, the occurrence of recruitment overfishing is not clear and there indications that is not the case yet. In the absence of up-to-date population 
parameters to define a more effective referential for the subject, the best alternative would be to drastically reduce the catch of juveniles and to observe the response of the stocks in the following fishing period.

Jaraquis, curimatã and matrinchã characterize a different biological context from tambaqui, as they have life-history parameters typical of r-strategists (Ribeiro, 1983; Zaniboni, 1985; Vazzoler et al., 1989; Oliveira, 1997). The reproductive characteristics of these species do not facilitate growth overfishing, since juveniles are not frequently accessible to the fishing gears most commonly used in the area (purse and beach seines). During up river dispersion migrations juveniles become more vulnerable to fishing; however, during this period, fishermen can also find adult individuals. Moreover, some special types of fishing gears (e.g. juvenile separator nets) are used for the fishing of pacu and of jaraqui (Batista, 1998), clearly indicating that the fishermen are trying to avoid the retention of the smaller individuals of these species.

The lack of oscillations in the production of curimatã and the stability in the catch index between 1994 and 1996 (Batista, 1998) suggest that the fishing pressure has not yet brought about perceptible effects on this species. In contrast, jaraqui landings showed a higher oscillation in the production and matrinchã, as well as pacu, showed periodic peaks in their production, with cycles of three years for pacu and four years for matrinchã. The gap in data from 1985 to 1993, however, preclude assessment of the constancy in this sequence. The marked variations in the production of matrinchã can be either linked to the generation of strong cohorts and/or by environmental conditions affecting the catchability of the adults (Batista, 1998).
The exceptional total production for the month of May during the three years of this study is associated with the downstream migration of the fat fish, fishes with large energy reserves for migration and reproduction (Ribeiro, 1983; Batista, 1998). In this type of migration, portions of the fish stock that usually fed within the flooded forest became available to the fishermen. On the other hand, the small production at the beginning of the flooding period is related to the migration strategy employed by the characiforms during this period. Moreover, from December until February, IBAMA set rules prohibiting the capture of some commercial species, which affects the statistics.

Scant information does not allow assessment of definitive patterns in the regional fishery. Assembling long series data about aquatic resources taken simultaneously from different systems in such a broad region like the Amazonia is very rare. Another important subject to be considered is the noise in the data due to the poor conditions of the landings in Manaus, to the dynamics of the fleet still under analyzed and to the dynamics of the resources, better known but still lacking some important answers. So, it is important that the fishing exploitation be monitored in a continuous way, and that the government and non governmental agencies be committed with the maintenance of the system, by allowing technical and scientific information to be used in the fishery sustainability in the region.

\section{LITERATURE CITED}

Barthem, R.B. 1990. Ecologia e pesca da piramutaba (Brachyplatystoma vaillantii). Tese de doutorado, UNICAMP, Campinas, SP. 268 pp. 
Barthem, R.B.; Goulding, M. 1997. The catfish connection: ecology, migration and conservation of Amazon predators. Columbia University Press., New York. 144 pp.

Batista, V.S. 1998. Distribuição, dinâmica da pesca e dos recursos pesqueiros na Amazônia Central. Tese de doutorado, INPA/FUA: 291 pp.

Bayley, P.B. 1981. Fish yield from the Amazon in Brazil: comparisons with African river yields and management possibilities. Transactions of the American Fisheries Society, 110: 351-359.

Bayley, P.B. 1983. Central Amazon fish populations: Biomass, production and some dynamic characteristics. Tese de doutorado, Dalhousie University. 330 pp.

Chapman, M.D. 1989 . The political ecology of fisheries depletion in Amazonia. Environmental Conservation 16(4): 331-337.

Ferreira, E.J.G.; Zuanon, J.; Santos, G.M. 1996. A list of commercial fish species from Santarém, State of Pará, Brazil. Naga, 19(3): 41-44.

Goulding, M. 1979. Ecologia da pesca no Rio Madeira. INPA, Manaus. 172 pp.

Goulding, M. 1981. Man and fisheries on an Amazon frontier. W. Junk Publications, The Hague, 132 pp.

Hilborn, R.; Walters, C.J. 1992. Quantitative fisheries stock assessment, Chapman and Hall, London. 570 pp.

Isaac, V.J.; Ruffino, M.L. 1996. Population dynamics of tambaqui, Colossoma macropomum Cuvier 1818, in the Lower
Amazon, Brazil. Fisheries Management and Ecology, (3): 315-333.

Junk, W.J. 1984. Ecology, fisheries and fish culture in Amazonia. . In: Sioli, H. (ed.) The Amazon: limnology and landscape ecology of a mighty tropical river and its basin. W. Junk Publications, Netherlands: p. 443-476

Junk, W.J.; Soares, M.G.M.; Saint-Paul, U. 1997. The fish.. In: Junk, W.J. (ed.) The Central Amazon Floodplain: Ecology of a pulsing system. Ecological Studies 126: p. 385-408.

Merona, B.; Bittencourt, M.M. 1988. A pesca na Amazônia através dos desembarques no mercado de Manaus: Resultados preliminares. Memoria Sociedad Ciencias Naturales La Salle, 48(Supl.2), 433-453.

Merona, B.; Gascuel, D. 1993. Effects of flood regime and fishing effort on the overall abundance of an exploited fish community in the Amazon floodplain. Aquatic Living Resources, 6(1): 97-108.

Oliveira, M.I.B. 1997. Idade e crescimento e aspectos da dinâmica populacional do curimatã Prochilodus nigricans (Pisces, Prochilodontidae) da Amazônia Central. Dissertação de mestrado, INPA/FUA, Manaus. $79 \mathrm{pp}$.

Payne, A.I. 1987. A preliminary stock assessment survey of the fishery at Trinidad in the Rio Mamoré. Relatório ODA, Londres. $34 \mathrm{pp}$.

Pereira-Filho, M., Guimarães, S., Storti Filho, A.; Graef, E.W. 1991. Piscicultura na Amazônia brasileira: entraves ao seu 
desenvolvimento. In: Val, A.L.; Figliuolo, R. \& Feldberg, E. (eds.) Bases cientificas para estratégias de preservação e desenvolvimento da Amazônia: Fatos e perspectivas. INPA, Manaus, AM. p. 373-380

Petrere Jr., M. 1978a. Pesca e esforço de pesca no estado do Amazonas. II. Locais e aparelhos de captura e estatística de desembarque. Acta Amazonica 8(Suplemento 2): 1- 54 .

Petrere Jr., M. 1978b. Pesca e esforço de pesca no estado do Amazonas. I- Esforço e captura por unidade de esforço. Acta Amazonica 8(3): 439-454.

Petrere Jr., M. 1982. Ecology of the fisheries in the river Amazon and its tributaries in the Amazonas States (Brazil). Tese de doutoramento, University of East Anglia, Norfolk. 96 pp.

Petrere Jr., M. 1983a. Relations among catches, fishing effort and river morphology for eight rivers in Amazonas State (Brazil), during 1976-1978. Amazoniana, 8(2): 281-296.

Petrere Jr., M. 1983b. Yield per recruit of the tambaqui, Colossoma macropomum Cuvier, in the Amazonas State, Brazil. Journal of Fish Biology, 22: 133-144.

Petrere Jr., M. 1985. A pesca comercial no rio Solimões-Amazonas e seus afluentes: Análise dos informes do pescado desembarcado no Mercado Municipal de Manaus (1976-1978). Ciência e Cultura, 37: 1987-1999.

Ribeiro, M.C.L.B. 1983. As migrações dos jaraquis (Pisces, Prochilodontidae) no Rio Negro, Amazonas, Brasil. Dissertação de mestrado. INPA - FUA, Manaus. 192 pp.
Roberts, T.R. 1972. Ecology of fishes in the Amazon and Congo basins. Bull. Mus. Com. Zool., 143(2):117-147.

Santos, G.M.; Jegu, M.; Merona, B. 1984. Catálogo de peixes comerciais do Baixo rio Tocantins. Eletronorte/CNPq/INPA, Manaus. $83 \mathrm{pp}$.

Smith, N. 1979. A pesca no Rio Amazonas. INPA/CNPq, Manaus. $154 \mathrm{pp}$.

Sokal, R.R.; Rohlf, F.J. 1981. Biometry. The principles and practice of statistics in biological research. W.H. Freeman and Company, New York. 859 pp.

Vazzoler, A . E.; Amadio, S; Caraciolo-Malta, M. C. 1989. Aspectos biológicos de peixes amazônicos. XII. Reprodução das espécies do gênero Semaprochilodus (Characiformes, Prochilodontidae) do Baixo Rio Negro, Amazonas, Brasil. Revista Brasileira de Biologia, 49(1): 165-173.

Villacorta-Correa, M. A. 1997. Estudo de idade e crescimento do tambaqui Colossoma macropomum (Characi-formes, Characidae) no Amazonas Central, pela análise de marcas sazonais nas estruturas mineralizadas e microestruturas nos otólitos. Tese de doutorado INPA/FUA, Manaus. $217 \mathrm{pp}$.

Zaniboni-Filho, E. 1985. Biologia da reprodução do matrinchã, Brycon cephalus (Gunther, 1869) (Teleostei, Characidae). Dissertação de Mestrado, INPA/FUA, Manaus.134 pp.

Submetido à publicação: 17/10/2000.

Aceito: 15/10/2002. 